$\stackrel{W}{=}$

Global journals Inc.

$(8)$

\title{
Vendors and Consumers Status and Microbial Analysis of Open Restaurant Foods in Patuakhali District University
}

By Sujan Kanti Mali, Md. Rabiul Haque, Liton Chandra Sen, Sourav Debnath \& Md. Hasan Rashid

Patuakhali Science and Technology University

Abstract- Open restaurant food vendor and consumer status as well as hygienic condition of different types of food at Dumki, Patuakhali upazila, and Kuakata union of Patuakhali district were determined. Ninety shops with 180 open restaurant food samples were collected. Among the food vendors, 97.78\% were male. Maximum (68\%) of them were between $21-40$ years of age. The majority (54\%) of them were primary educated. Half of the vending shops located on the sidewalk and one third on the footpath. The majority $(81 \%)$ of the respondent had their daily net profit up to TK. 500 . About $64 \%$ of vendors did not cover their food while selling; $47.78 \%$ used unclean towels and $27.78 \%$ used plate followed by paper \& polythene $(49.45 \%)$ as a serving media. Everyone used tube-well water as drinking water. The few had a business permit or food-selling permit. Maximum (83.33\%) consumers were male, and the highest consumers $(76.667 \%)$ were aged between $21-40$ years. The majority $(57.77 \%)$ of consumers always consume foods on roadside. $60 \%$ of the consumers suffered from diseases. Only $4.44 \%$ of consumer had enough knowledge about nutrition and $8.89 \%$ in hygiene.

Keywords: open restaurant; vendor; microbial analysis; salmonella; E. coli.

GJMR-C Classification: NLMC Code: QW 4

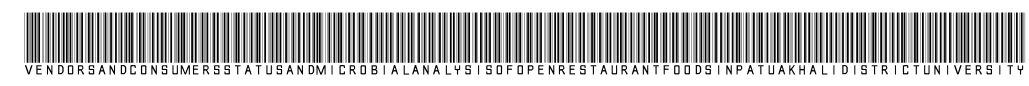

Strictly as per the compliance and regulations of:

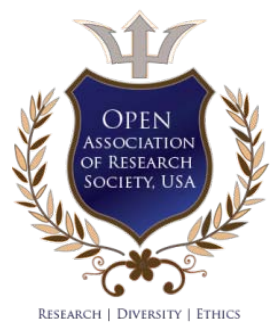

(C) 2020. Sujan Kanti Mali, Md. Rabiul Haque, Liton Chandra Sen, Sourav Debnath \& Md. Hasan Rashid. This is a research/review paper, distributed under the terms of the Creative Commons Attribution-Noncommercial 3.0 Unported License http://creativecommons.org/licenses/by-nc/3.0/), permitting all non-commercial use, distribution, and reproduction in any medium, provided the original work is properly cited. 


\title{
Vendors and Consumers Status and Microbial Analysis of Open Restaurant Foods in Patuakhali District
}

\author{
Sujan Kanti Mali ${ }^{\alpha}$, Md. Rabiul Haque $^{\sigma}$, Liton Chandra Sen ${ }^{\rho}$, Sourav Debnath ${ }^{\omega} \&$ Md. Hasan Rashid ${ }^{*}$
}

\begin{abstract}
Open restaurant food vendor and consumer status as well as hygienic condition of different types of food at Dumki, Patuakhali upazila, and Kuakata union of Patuakhali district were determined. Ninety shops with 180 open restaurant food samples were collected. Among the food vendors, $97.78 \%$ were male. Maximum (68\%) of them were between $21-40$ years of age. The majority (54\%) of them were primary educated. Half of the vending shops located on the sidewalk and one third on the footpath. The majority (81\%) of the respondent had their daily net profit up to TK. 500. About $64 \%$ of vendors did not cover their food while selling; $47.78 \%$ used unclean towels and $27.78 \%$ used plate followed by paper \& polythene (49.45\%) as a serving media. Everyone used tube-well water as drinking water. The few had a business permit or food-selling permit. Maximum (83.33\%) consumers were male, and the highest consumers $(76.667 \%)$ were aged between $21-40$ years. The majority $(57.77 \%)$ of consumers always consume foods on roadside. $60 \%$ of the consumers suffered from diseases. Only $4.44 \%$ of consumer had enough knowledge about nutrition and $8.89 \%$ in hygiene. About all food items contained E. coli. and salmonella. Water and salad was fully contaminated by this microorganism.
\end{abstract}

Keywords: open restaurant; vendor; microbial analysis; salmonella; E. coli.

\section{INTRODUCTION}

$\longrightarrow$ pen restaurant food vending and consuming is a popular type of informal self-employment in the Patuakhali district, providing the vendors with a means to sustain their livelihoods. Vendors sell a great variety of products from different kinds of vending units. A study in Uganda (Ayalew, M. S., 2008) showed that most vendors earned more than the minimum civil

Author a: Assistant Professor, Department of Biochemistry and Food Analysis, Patuakhali Science and Technology University, Patuakhali. e-mail:sk@pstu.ac.bd

Author o: Professor, Department of Biochemistry and Food Analysis, Patuakhali Science and Technology University, Patuakhali. e-mail:dr rabiul@pstu.ac.bd

Author p: Associate Professor, Department of Biochemistry and Food Analysis, Patuakhali Science and Technology University, Patuakhali. e-mail: Liton.sen@pstu.ac.bd

Author w: Assistant Professor, Department of Biochemistry and Food Analysis, Patuakhali Science and Technology University, Patuakhali. e-mail: dsouravpstu@gmail.com

Author ¥: Scientific Officer, Crop Zoning Project, Bangladesh Agricultural Research Council, Farmgate, Dhaka-1215.

e-mail: hasanjkbd@gmail.com service wage and many earned more than the minimum wage. In developing countries, drinks, meals, and snacks sold by street food vendors widely consumed by millions of people (FAO, 1988). In Bangladesh, the quality and quantity of food supplies by vendor systems are not so inadequate but unhygienic for health. The street foods provide an affordable source of nutrients to many sectors of the population (Ohiokpehai, 2003). Within this context, street foods as informal food supply system, opportunities for resource- poor groups in urban and peri-urban environments, not only as a means of employment but also as an effective way of providing low-cost nutrition to the people (Codjia, 2000).

The present study also showed a daily income of vendors to be up to TK. 1746.50 with a net profit up to TK. 283.00./day. Though this figure is not that encouraging, however, when the credibility in terms of safety of street foods will increase, it will contribute to better earnings of the vendors. They tied to retailers, cooking units, and other food system actors. Specific consumer groups with street food eating habits found to exist. Among various types of informal sector activities, food vending is distinctive in the sense that it provides a need for the urban inhabitants and involves issues of hygiene and food safety. A large number of dwellers from different spheres of life such as students, tourists, rickshaw drivers, cart pullers, and other such workers rely on open restaurant food vendors for their daily meals. Urban food vending provides employment and income for many people. However, street foods are frequently associated with many food and water born disease like, diarrhea, hepatitis, typhoid, etc diseases due to their handlings and use of dirty water. The open restaurant foods vendors are not aware of all about health hygienic and microbial aspects of food and drinking water. Especially the coastal belt of Bangladesh is naturally rich in soil and water-borne pathogens.

\section{il. Materials and Methodology}

a) Sample selection and sample size

90 open restaurants and 90 consumers included in the present survey were therefore, a purposive sample chosen primarily to represent some of the key characteristics associated with them. 
b) Interview schedule design

The interview schedule developed for collecting socioeconomic information, health aspects of food, and environmental aspects of food after developing the Interview schedule it was pre-tested among five sellers, and five consumers and necessary correction done for the final Interview schedules. Those Interview schedule field tested, modified, and standardized.

c) Equipment and general procedure for microbial examination

i. All glass equipment, e.g., Petri dish, Pipette, Test tube, Beaker \& other glass wares were washed, rinsed, dried, and treated a hot air oven for sterilization. Sterilization is done by dry heat at $170^{\circ} \mathrm{C}$ for 1 hour.

ii. All the media prepared for microbial growth sterilized by steam pressure using lat at $15 \mathrm{lb} /$ square inch pressure for 5 minute.

\section{d) Preparations of food samples}

Homogenate food samples prepared by taking $10 \mathrm{gm}$ of both superficial \& inner layers of samples and weighed on a sterile weighing paper using sterile scalpels or forceps, and washing with alcohol before \& each batch of samples and between samples washed with hot water and sterilized with alcohol. These meshed samples inserted aseptically into sterile cotton plugged conical flask containing $0.9 \%$ sterile sodium chloride solution by using sterile forceps.

\section{e) Bacteriological analysis}

Three different types of media were recommended for the growth of Salmonella and E. coli. The colonies developed on the plates and counted after incubation for $24-48$ hours at $37^{\circ} \mathrm{C}$ and $\mathrm{pH}$ of the media adjusted to 7.2 prior to sterilization. Inoculated plates incubated at $37 \mathrm{C}$ for $24-48$ hours to facilitate viable bacterial growth.

\section{f) Total aerobic plate count}

Duplicate pour plates of four successive decimal dilutions prepared. The plates incubated at $37^{\circ} \mathrm{C}$ for $24-48$ hours, and duplicate plates counted and calculated. Average counts expressed as colonyforming units per gram or $\mathrm{ml}$ of sample.

\section{g) Coliform count}

The coliform count of the food and water samples determined using membrane filter technique. The plates incubated at $35^{\circ} \mathrm{C}$ for 24 hours.

h) Data management and analysis

The quality of the data entry process commenced as the questionnaires collected from the surveyed areas after the process of cleaning the mistakes. Data entry process managed to apply doubledata entry errors. All questionnaires edited and the data were cleaned, and entered into a computer. The data were analyzed by SPSS 20.0 package. Results expressed as frequencies and percentages.

\section{ili. Results}

\section{a) Results of open restaurant food vendor}

i. Socio-economic and demographic profile of open restaurant food vendors

Most of the vendors were male (97.78\%). About $68 \%$ of them were age between 21-40 years (mean about 31 years) while, 23.33\% were age between 41-60 years. About $73.33 \%$ of vendors were married, $43.33 \%$ of them had a family size of 5 or less, and the rest $56.67 \%$ had a family size higher than 5 . About $54 \%$ of vendors who had primary education followed by nearly $10 \%, 5.56 \%$, and $5.56 \%$ vendors had SSC, HSC, and Degree education respectively, and $24.44 \%$ of vendors were illiterate. Only $3.33 \%$ of vendors in Patuakhali had Degree education while, $20 \%$ of them were illiterate in Dumki comprising the lowest percentage among the three survey areas.

ii. Ownership and reason for doing food vending business

The survey, it was revealed that $74.45 \%$ vendors owned and half of the vendors $(51.11 \%)$ had the opinion that due to the low investment, and skill required they had come into the open restaurant food vending business (Figures 1). 


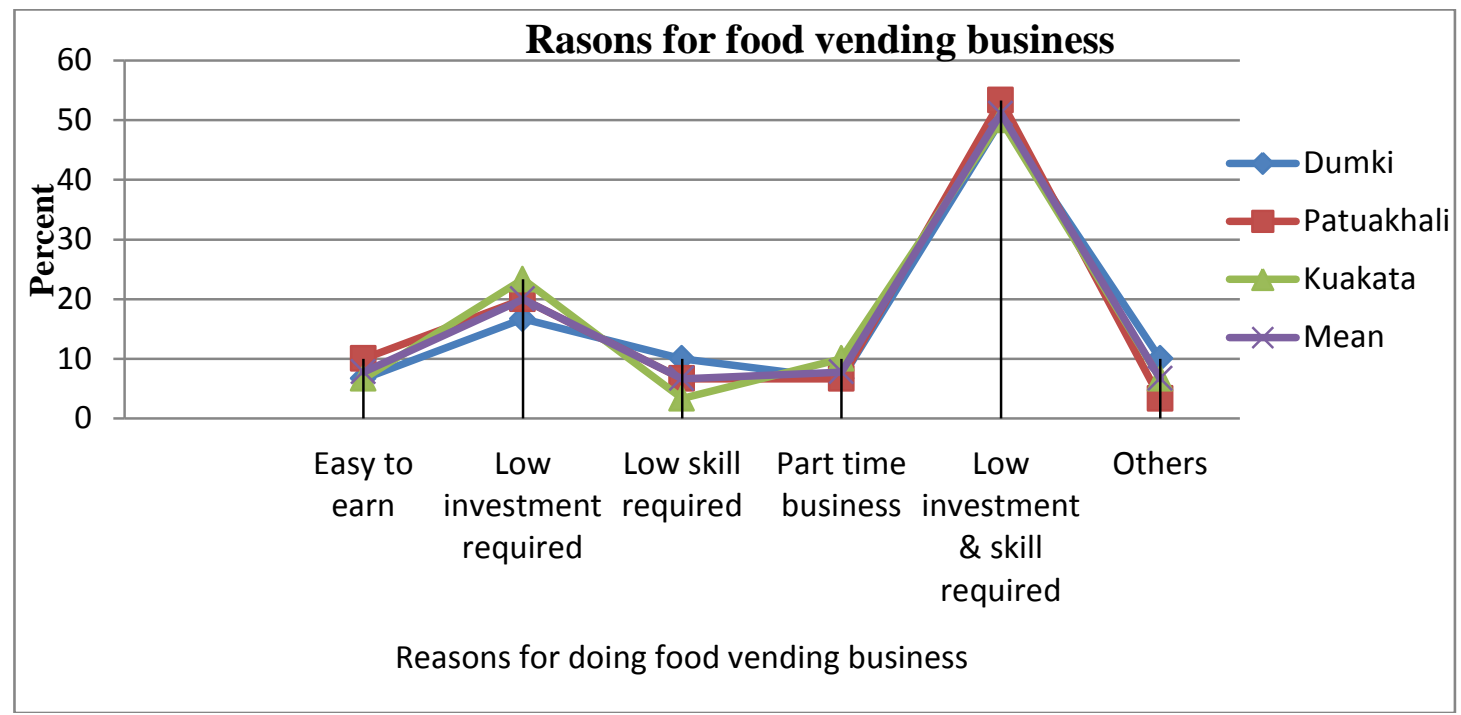

Figure 1: Reasons for food vending business of the open restaurant food vendor

iii. Nature of shop and the vending business

An open restaurant business requires medium investment. Most of the vendors own the business and reportedly work for 13-18 hours, running their open restaurant food vending as the principal business. Some members are engaged in open restaurant food vending business as their principal business though they have other income sources. Some vendors are solely engaged in open restaurant food vending as they do not have any other business. A small number of vendors engaged in part- time food vending. Nearly $82.22 \%$ of the food vendors reported it was their principal business while only $17.78 \%$ of them accepted open restaurant food vending as a part-time.

iv. Length and period of business of street food vending

The majority of the open restaurant food vendors had been doing business from 4 to 10 years in respective of the areas surveyed with the mean is $38.887 \%$. In Kuakata, no open restaurant food vendors had been starting business up to one year.

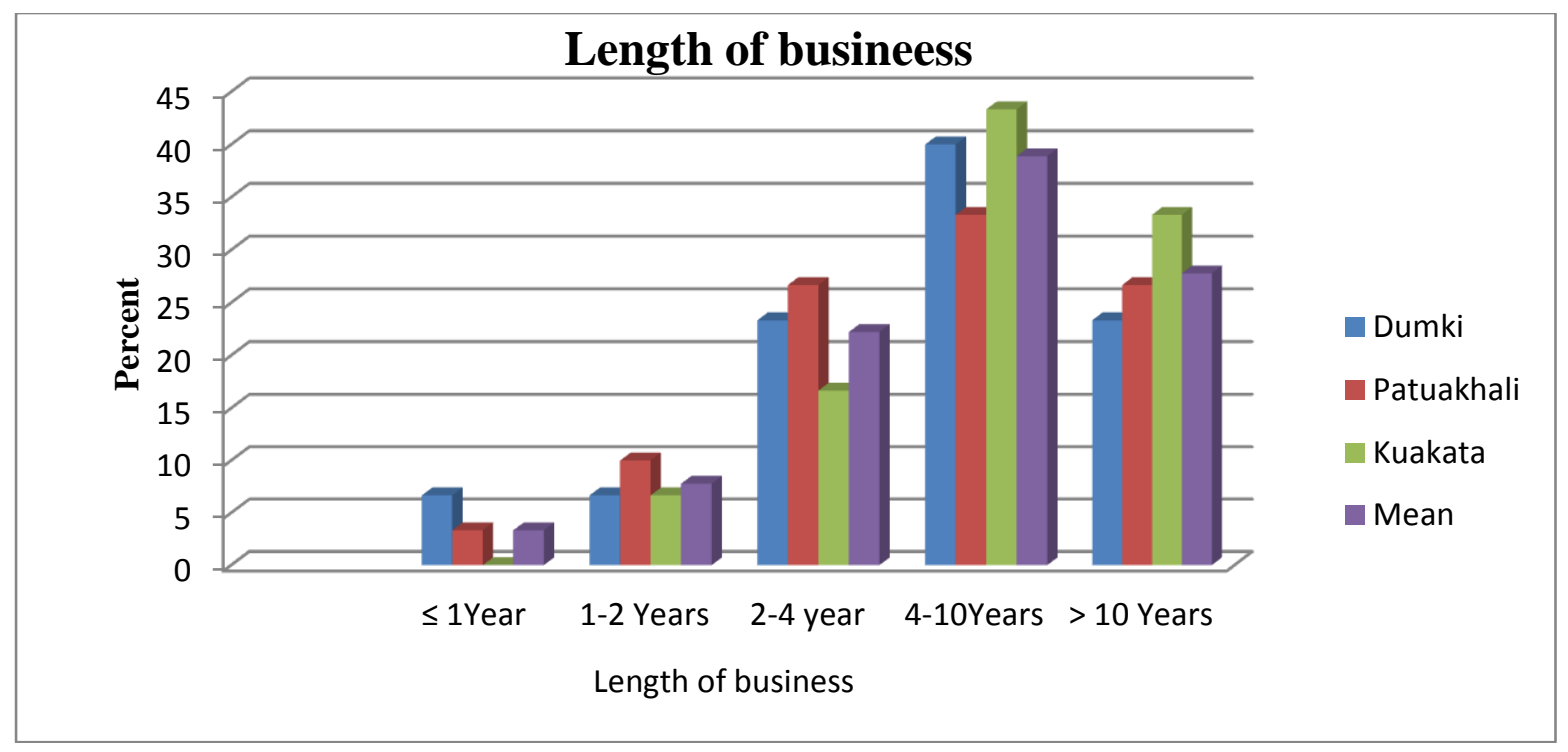

Figure 2: Length of business of the open restaurant food vendor

\section{v. Location and proximity of vending shops}

During the survey, it was revealed that 43.33 of the vending shops located on the sidewalk and $33 \%$ on the footpath in three survey areas and the rest in all other possible areas (near aisles of the bazaar, school, restaurant and office vicinity. $46.67 \%$ of food vending shops in Dumki and $40 \%$ in the Patuakhali area and nearly $30 \%$ vending business in the Kuakata area 
located near the side of drain, sewerage, toilet and dustbins.

vi. Nature of business and daily capital/net profit

The vendors were unsatisfied about their investment, daily income, and net profit of the food vending business. Forty-one percent of vendors invested up to TK. 100000 in their business. Nearly $40 \%$ of vendors' daily sales range between TK. 1001-2000 and $81 \%$ make a net profit of more than TK. 500 daily. It observed that the average investment was higher in the Kuakata area amount in TK 97383 and less in Dumki amount in TK 78000. Patuakhali area placed in between the other two with TK 97333. However, more than 50\% of vendors reported that net profit met $100 \%$ of their family expenditure.

Table 1: Daily capital/sale profile of the open restaurant food vendor

\begin{tabular}{|c|c|c|c|c|}
\hline Upazila Name & Minimum (TK) & $\begin{array}{l}\text { Maximum } \\
\text { (TK) }\end{array}$ & $\begin{array}{l}\text { Mean } \\
\text { (TK) }\end{array}$ & Standard Deviation \\
\hline \multicolumn{5}{|c|}{ Investment of the open restaurant food vendors } \\
\hline Dumki & 20000 & 300000 & 78000 & \pm 39315.57 \\
\hline Patuakhali & 20000 & 250000 & 97333 & \pm 49320.274 \\
\hline Kuakata & 1500 & 320000 & 97383 & \pm 57894.95 \\
\hline \multicolumn{5}{|c|}{ Daily income of the open restaurant food vendors } \\
\hline Dumki & 1000 & 6000 & 3780 & \pm 1954.023 \\
\hline Patuakhali & 1000 & 7000 & 4,395 & \pm 2064.84 \\
\hline Kuakata & 1500 & 8000 & 5400 & \pm 1975.15 \\
\hline \multicolumn{5}{|c|}{ Daily net income of the open restaurant food vendors } \\
\hline Dumki & 400 & 2400 & 1,357 & \pm 485.43 \\
\hline Patuakhali & 450 & 2500 & 1140 & \pm 560.54 \\
\hline Kuakata & 500 & 3000 & 1,653 & \pm 691.34 \\
\hline \multicolumn{5}{|c|}{ Shop rent of the open restaurant food vendors } \\
\hline Dumki & 1200 & 3000 & 2005.556 & \pm 485.64 \\
\hline Patuakhali & 1000 & 3500 & 2278.261 & \pm 674.17 \\
\hline Kuakata & 1200 & 5000 & 2133.33 & \pm 866.79 \\
\hline
\end{tabular}

vii. Working schedule of the vendors

During the survey, it was revealed that (86.667\%) worked all time. Food vending in residential areas was comparatively higher (90\%). Seventy-five percent of the vendors worked for 13-18 hours in a day. The maximum sale was at noon and lowest was at morning. Winter was the season of maximum sale and while minimum during the summer. It was difficult to maintain the vending during the summer and rainy season, and consumers did not go outside. Winter season was more comfortable for both vendors and consumers. The majority $(57.22 \%)$ of the vendors continued their business from morning to midnight. $77.23 \%$ of vendors washed their hand before preparing foods. However, $60 \%$ food handlers did not clear their hands before serving food which support the report of' Bangkok where over $60 \%$ of street food vendors washed preparation equipments and eating utensils once it day (FAO, 1994).

\section{viii. Licenses/permits}

About $67 \%$ of the vendors replied when they asked whether they had to pay shop rent for doing their vending businesses. The rest $33 \%$ of vendors had own shop. All vendors agreed that they did not pay money to the Police, market committee, and others. Over $100 \%$ of the street food vendors felt they should have a license for their business but, $74.44 \%$ had. The few, who said they had the licenses, had a business permit or foodselling permit. The food vendors told whether they had any training on food safety and food serving or not. Cent percent of the vendors had no training either on food safety or on food serving irrespective of the survey areas.

\section{ix. Food safety profile}

In street food vending, the raw material source was important as their contamination from this point could persist through preparation, processing, and cooking. Quality of the raw materials were important to the safety of vended food because of the biological, chemical and physical hazards that might be introduced to the vending operations and which may persist through preparation and processing.

a. Water, environment, sanitation and personal hygiene

Cent percent reported that the source of drinking water for consumers was stored water that was collected from the nearby tube well. The water always stored in plastic drums without lids, thus making it more susceptible to contamination. Most of the male labor brings water, and $67.777 \%$ bring 3 or less. 
Table 2: Water management of the open restaurant food vendors in percentage $(n=90)$

\begin{tabular}{|c|c|c|c|c|}
\hline Characteristics & Dumki & Patuakhali & Kuakata & Mean \\
\hline water bringing person & 93.33 & 90 & 93.33 & 92.22 \\
\hline Male labor & 6.67 & 10 & 6.67 & 7.78 \\
\hline Female labor & 66.67 & 73.33 & 63.33 & 67.78 \\
\hline Water bringing times & 33.33 & 26.67 & 36.67 & 32.22 \\
\hline$<=3$ & \multicolumn{5}{l}{} \\
\hline > 3 & 6.67 & 10 & 66.67 & 27.78 \\
Have own tube well & 93.33 & 90 & 33.33 & 72.22 \\
\hline Yes & 10 & 13.33 & 6.67 & 10 \\
No & 6.67 & 6.67 & 3.33 & 5.56 \\
Water disposal place & 40 & 43.33 & 36.67 \\
\hline Drain & 6.67 & 40 & 46.67 & 47.78 \\
\hline
\end{tabular}

\section{b. Safe water using practices}

One of the striking findings found in the survey was that $100 \%$ of vendors did not take any measures for purification of drinking water, which implies a definite possibility of contamination. Drinking water did not boil irrespective of the location.

$\mathrm{x}$. Mode of display of food by open restaurant vendor

The majority of the vendors displayed their foods in baskets/trays, bowl, and shelves in survey area while vendors used showcase in Patuakhali and Kuakata areas. The utensils they used made up of many different materials such as melamine, aluminum, stainless steel, and ceramics. Some vendors used only paper instead of a plate. Tissue paper used $68.89 \%$ of vendors.

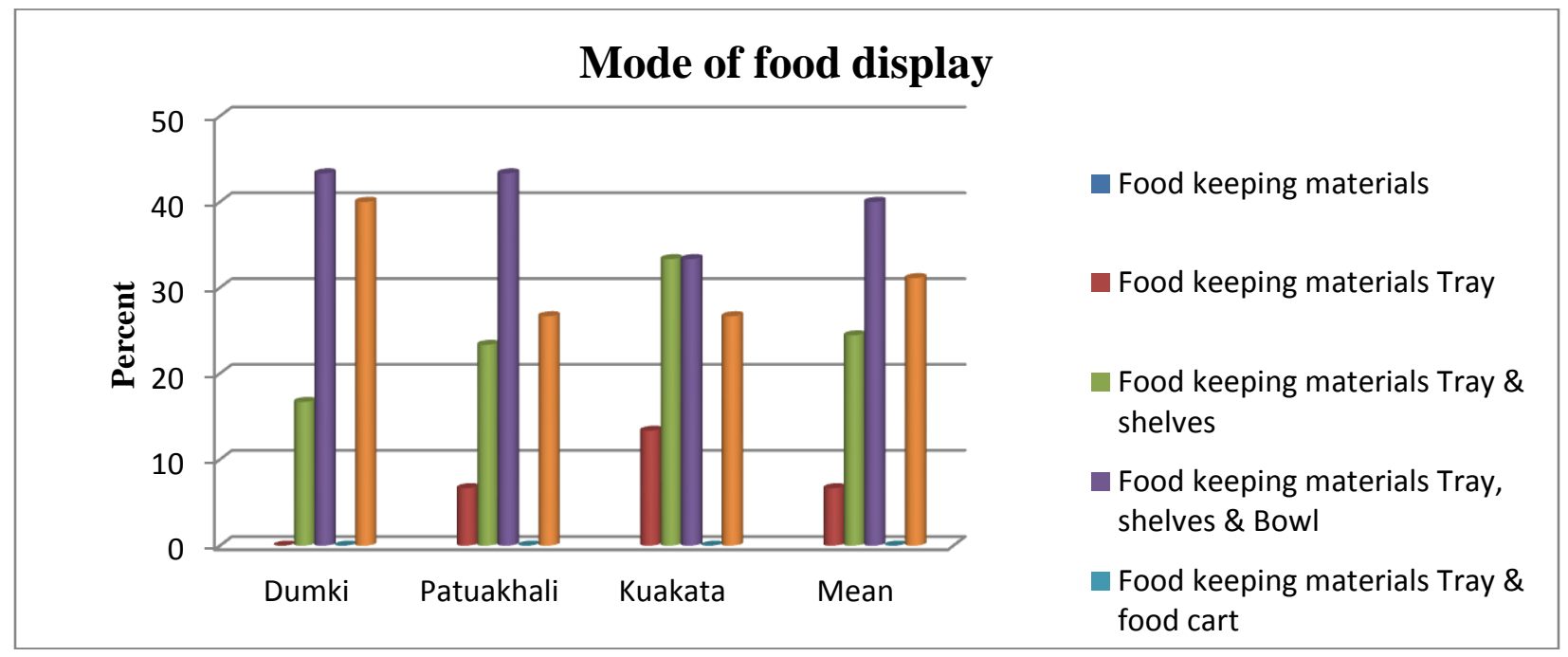

Figure 3: Mode of food display by the open restaurant food vendor

Table 3: Utensil of serving food of the open restaurant food vendors

\begin{tabular}{|c|c|c|c|c|}
\hline Characteristics & Dumki & Patuakhali & Kuakata & Mean \\
\hline Utensil During Serving food (\%) & 0 & 0 & 0 & 0 \\
\hline Paper & 16.67 & 23.33 & 33.33 & 24.443 \\
plate & 0 & 0 & 0 & 0 \\
Cup \& Glass & 83.33 & 76.67 & 66.67 & 75.557 \\
Plate \& Polythene & 0 & 0 & 0 & 0 \\
Cup, Glass \& Spoon &
\end{tabular}




\section{xi. Protective display of food}

About $64 \%$ of the vendors did not cover their food during selling. $56.67 \%$ cleaned the utensils in their shop but $13 \%$ on the roadside. Two thirds of food vendors used stored water for cleaning the utensil. The time between food making, and food selling more than 5 hours was $61.11 \%$, and $38.89 \%$ was 5 or less. Ninety percent of open restaurant vendors used soybean oil and frequency of using oil was one used by $70 \%$ of the vendors.

\section{xii. Food servicing system of open restaurant food vendor}

Eighty-three percent of the vendors served food to the consumers with plate and polythene in Dumki area as against $66.67 \%$ vendors who used plate in Kuakata area. About $28.89 \%$ of the vendors disposed of their garbage in the pond, and (27.78\%) threw them in the drain and roadside. Pond and river was the place of best choice (about 47.78\%) and $36.667 \%$ on the roadside for disposal of used water. The use of public toilets or open places outside was the highest among the vendors. Some of the vendors used their own house as the second option. In all areas surveyed, almost all vendors washed their hands using soap water after toilet.

Table 4: Percent water and sanitation profile of the open restaurant food vendors $(n=90)$

\begin{tabular}{|c|c|c|c|c|}
\hline Characteristics & Dumki & Patuakhali & Kuakata & Mean \\
\hline \multicolumn{5}{|l|}{ Place of utensils clean } \\
\hline Shop & 60 & 53.33 & 56.67 & 56.67 \\
\hline Own house & 16.67 & 6.67 & 6.67 & 10 \\
\hline Roadside & 10 & 13.33 & 16.67 & 13.33 \\
\hline Others(Pond, River etc) & 13.33 & 26.67 & 20 & 20 \\
\hline \multicolumn{5}{|c|}{ Type of water used to clean utensils } \\
\hline Stored water & 63.33 & 60 & 83.33 & 68.89 \\
\hline Tap water & 0 & 3.33 & 0 & 0.11 \\
\hline River water & 23.33 & 26.67 & 0 & 16.67 \\
\hline Others & 13.33 & 10 & 16.67 & 13.33 \\
\hline \multicolumn{5}{|l|}{ Garbage disposal } \\
\hline Dustbin & 10 & 3.33 & 16.67 & 10 \\
\hline Drain & 6.67 & 10 & 0 & 5.56 \\
\hline Road side & 16.67 & 26.67 & 40 & 27.78 \\
\hline Pond & 40 & 30 & 16.67 & 28.89 \\
\hline River & 16.67 & 23.33 & 0 & 13.33 \\
\hline Others & 10 & 6.67 & 26.67 & 14.45 \\
\hline \multicolumn{5}{|l|}{ Toilet uses } \\
\hline Public toilet & 53.33 & 53.33 & 33.33 & 46.67 \\
\hline Shop toilet & 30 & 40 & 60 & 43.33 \\
\hline Own house & 16.67 & 6.67 & 6.67 & 10 \\
\hline Neighbor house & 0 & 0 & 0 & 0 \\
\hline Roadside & 0 & 0 & 0 & 0 \\
\hline Others & 0 & 0 & 0 & 0 \\
\hline \multicolumn{5}{|c|}{ Washing hands after using the toilet } \\
\hline Yes & 100 & 100 & 100 & 100 \\
\hline No & 0 & 0 & 0 & 0 \\
\hline Sometimes & 0 & 0 & 0 & 0 \\
\hline \multicolumn{5}{|c|}{ Washing hand before food preparation } \\
\hline Always & 76.67 & 80 & 70 & 75.56 \\
\hline Sometimes & 16.67 & 20 & 30 & 22.22 \\
\hline Very few times & 6.67 & 0 & 0 & 2.22 \\
\hline Never & 0 & 0 & 0 & 0 \\
\hline \multicolumn{5}{|l|}{ Washing hands before food serving } \\
\hline Always & 43.33 & 53.33 & 40 & 45.55 \\
\hline Sometimes & 56.67 & 46.67 & 60 & 54.45 \\
\hline Once a day & 0 & 0 & 0 & 0 \\
\hline Never & 0 & 0 & 0 & 0 \\
\hline \multicolumn{5}{|l|}{ Cleaning time of dirty plate } \\
\hline Morning & 6.67 & 10 & 3.33 & 6.67 \\
\hline Noon & 0 & 0 & 0 & 0 \\
\hline After noon & 0 & 0 & 0 & 0 \\
\hline
\end{tabular}




\begin{tabular}{|c|c|c|c|c|}
\hline Night & 6.67 & 16.67 & 20 & 14.44 \\
Throughout the day & 86.67 & 73.33 & 76.67 & 78.89 \\
Morning to Mid night & 0 & 0 & 0 & 0 \\
\hline
\end{tabular}

xiii. Source of food sold by the vendors

A majority of the vendors prepared their food at home and brought to the streets for marketing. A single vendor was engaged in selling more than one food item. Almost 55.557\%t of food vendor cooked/prepared foods in advance in their hotel kitchen while $28.89 \%$ vendors bought their foods for vending from open front place etc. $11.11 \%$ of vendors brought cooked food from home, $5.556 \%$ of vendors prepared food from other places remain for ready to eat.

Table 5: Food selling time of open restaurant vendors

\begin{tabular}{|c|c|c|c|c|}
\hline Characteristics & Dumki & Patuakhali & Kuakata & Mean \\
\hline Food selling time (\%) & 0 & 0 & 0 & 0 \\
\hline Only Morning & 0 & 0 & 0 & 0 \\
Only Noon & 0 & 0 & 0 & 0 \\
Only After noon & 0 & 0 & 0 & 0 \\
Only Night & 6.67 & 13.33 & 13.33 & 11.110 \\
Throughout the day & 93.33 & 86.67 & 86.67 & 88.890 \\
Morning to Mid night &
\end{tabular}

xiv. Personal hygiene of the open restaurant vendors

All of them usually did not cover their head during vending, $47.78 \%$ used dirty towels. But nearly $80 \%$ of the vendors' cut their nails properly, and $61.11 \%$ wore neat and clean attire. None was found to use hand gloves. Ninety percent of open- restaurant vendors did not cover their heads during vending.

$\mathrm{xv}$. Supervision and monitoring of the open restaurant food vendors

About $88.89 \%$ of open restaurant vendors said that shops supervised regularly, and $87.65 \%$ were mobile court. Supervision occurred yearly and fined several times

xvi. Open restaurant food ingredient

Most of the vendors $(93.33 \%)$ said that street food ingredients were bought from Kacha markets and
$34.443 \%$ store in the shop and kept the prepared food in open showcase told $33.333 \%$ of vendors.

xvii. Knowledge regarding food nutrition of the consumer

Knowledge regarding food nutrition was not satisfactory. Only $4.44 \%$ of consumers had well knowledge about nutrition and $8.89 \%$ in hygiene. Food safety, food serving and other was very dull. Food preparation and hotel management knew moderately $66.67 \%$, and $55.557 \%$ of vendors. The food serving practice was very poor. Fifteen percent vendors did not know about food safety. Fifty-one percent moderately knew consumers perception.

Table 6: Percent knowledge regarding food nutrition of the open restaurant food vendors $(n=90)$

\begin{tabular}{|c|c|c|c|c|c|c|c|}
\hline Characteristics & Location & Well & Not so well & Moderate & Bad & Very bad & None \\
\hline \multirow{5}{*}{ Nutritional } & Dumki & 3.33 & 6.67 & 20 & 23.33 & 40 & 6.67 \\
& Patuakhali & 3.33 & 10 & 26.67 & 26.67 & 23.33 & 10 \\
& Kuakata & 6.67 & 10 & 26.67 & 20 & 26.67 & 10 \\
\cline { 2 - 8 } & Mean & 4.44 & 8.89 & 24.45 & 23.33 & 30 & 8.89 \\
\hline \multirow{5}{*}{ Hygiene } & Dumki & 0 & 20 & 30 & 36.67 & 13.33 & 0 \\
& Patuakhali & 0 & 10 & 36.67 & 30 & 23.33 & 0 \\
\cline { 2 - 8 } & Kuakata & 3.33 & 13.33 & 33.33 & 26.67 & 20 & 3.33 \\
\cline { 2 - 8 } Food preparation & Mean & 1.11 & 14.44 & 33.33 & 31.11 & 18.89 & 1.11 \\
\hline \multirow{5}{*}{ Food safety } & Dumki & 0 & 0 & 83.33 & 10 & 6.67 & 0 \\
& Patuakhali & 0 & 0 & 76.67 & 13.33 & 10 & 0 \\
& Kuakata & 0 & 3.33 & 66.67 & 16.67 & 13.33 & 0 \\
\cline { 2 - 8 } & Mean & 0 & 1.11 & 75.56 & 13.33 & 10 & 0 \\
\hline & Dumki & 0 & 0 & 10 & 40 & 33.33 & 16.67 \\
& Patuakhali & 0 & 0 & 13.33 & 43.33 & 26.67 & 16.67 \\
\cline { 2 - 8 } & Kuakata & 3.33 & 6.67 & 20 & 33.33 & 23.33 & 13.33 \\
\hline & Mean & 1.11 & 2.22 & 14.44 & 38.89 & 27.78 & 15.56 \\
\hline
\end{tabular}




\begin{tabular}{|c|c|c|c|c|c|c|c|}
\hline \multirow{3}{*}{ Food serving } & Dumki & 0 & 16.67 & 33.33 & 33.33 & 16.67 & 0 \\
& Patuakhali & 0 & 13.33 & 40 & 30 & 16.67 & 0 \\
& Kuakata & 0 & 16.67 & 43.33 & 26.67 & 13.33 & 0 \\
\cline { 2 - 8 } & Mean & 0 & 15.56 & 38.89 & 30 & 15.56 & 0 \\
\hline
\end{tabular}

xviii. Consumer aspect of the open restaurant food vendors

In the survey, it was observed that $100 \%$ vendor told tourists was the regular customer, and no student ate there. On the other hand in Dumki and Patuakhali Upazila there were no tourists. Most of the vendors said that Labor, Rickshaw puller and Driver was the regular customer. Seventy percent vendor's opinion was consumers ate these foods for easy access and safe time. Open restaurant food supply proper nutrient told $58.887 \%$ of vendors.

Table 7: Consumer aspect of the open restaurant food vendors

\begin{tabular}{|c|c|c|c|c|c|c|}
\hline \multicolumn{7}{|c|}{ Regular Customer (\%) } \\
\hline Location & Student & Labor & $\begin{array}{c}\text { Rickshaw } \\
\text { puller }\end{array}$ & Driver & $\begin{array}{c}\text { General } \\
\text { people }\end{array}$ & Tourist \\
\hline Dumki & 50 & 93.33 & 76.67 & 73.33 & 53.33 & 0 \\
Patuakhali & 56.67 & 90 & 80 & 76.67 & 56.67 & 0 \\
Kuakata & 0 & 83.33 & 66.67 & 70 & 53.33 & 100 \\
\hline Mean & 35.35 & 88.887 & 74.447 & 73.333 & 54.443 & 33.33 \\
\hline \multicolumn{7}{|c|}{ Why consumers buy these foods? (\%) } \\
\hline Location & Taste & Cheaper & Safe time & Easy & Nutrient & Others \\
\hline Dumki & 33.33 & 16.67 & 83.33 & 86.67 & 60 & 0 \\
Patuakhali & 46.67 & 23.33 & 73.33 & 80 & 63.33 & 10 \\
Kuakata & 53.33 & 26.67 & 60 & 50 & 53.33 & 13.33 \\
Mean & 44.443 & 22.223 & 72.220 & 72.223 & 58.887 & 7.777 \\
\hline
\end{tabular}

xix. Types of vended food

Most of the vendors sold food item such as rice, fish, meat, brainy, vegetables ect.

Table 8: Types of vended food of the open restaurant food vendors

\begin{tabular}{|c|c|c|c|c|c|c|c|c|}
\hline \multicolumn{10}{|c|}{ Types of vended food } \\
\hline Location & Rice & Fish & Egg curry & Chicken & Beef & Bread & Khichuri & Brainy \\
\hline Dumki & 100 & 96.67 & 100 & 66.67 & 50 & 53.33 & 56.67 & 40 \\
Patuakhali & 100 & 100 & 93.33 & 70 & 46.67 & 43.33 & 33.33 & 46.67 \\
Kuakata & 100 & 100 & 56.67 & 90 & 56.67 & 83.33 & 16.67 & 80 \\
\hline Mean & 100.00 & 98.8 & 83.333 & 75.557 & 51.11 & 59.99 & 35.55 & 55.55 \\
\hline
\end{tabular}

b) Results of consumers of Open Restaurant food

i. Socio-demographic characteristics of the consumers

Among the interviewed consumers maximum were male (83.33\%) and age ranged between 10-60 years. It found that majority of them were married (55.577\%), and $1.11 \%$ of divorced. A majority consumer had S.S.C/ H.S.C. education (34.66\%) followed by Illiterate (10\%), and higher educated (30\%). Consumers were from different occupations. The majority of them were students $(38.89 \%)$ followed by the business (32.223\%), and employer (14.4\%). Maximum (31.113\%) consumer was with no income.

ii. Nature of consuming area of the consumer

Most of the consuming areas (57.78\%) were station; middle classes were $36.667 \%$, and slum $5.557 \%$. In Dumki $70 \%$ of consumers consumed food in the station. iii. Personal hygiene of the consumers

The survey report of the consumers observed that almost $68.89 \%$ found to use a clean dress. But $72 \%$ of the consumers cut their nails properly. None found to use hand gloves during survey conducted. Vaccinated consumers were $52.223 \%$ of the total consumers.

\section{iv. Personal hygiene}

The source of drinking water collected from the nearby tube well and stored in plastic drums without lids. Before food eating, $44.447 \%$ of consumers washed hand, and never washed hand at $21.11 \%$. The majority percent $(75.557 \%)$ of consumers said that vendors cleaned their dirty plates throughout the day; Most of the consumer $(61.113 \%)$ told foods did not clean and $52.223 \%$ told foods were not cover properly. Cleaning table and food serving done the same person. Used water disposed at the roadside. 
v. Mode of display of street food

The majority of the vendors displayed their foods in baskets/trays, bowl, and shelves, while vendors used showcase. About $38.89 \%$ of consumers had no idea of food preservation and $46.667 \%$ told vendors preserved food normally. A majority of consumers consumed always in road side. Major portion of consumer's ate roadside foods as it was safe time and easy access, although only $61.11 \%$ of them received it as unhygienic food. The same report found in Peru where the sanitary conditions utensils and tables judged to be substandard in 76 to $89 \%$ of the inspection (FAO, 1990).

vi. Knowledge regarding food nutrition of the consumer

Knowledge regarding foods nutrition of the consumers was not satisfactory. Only $22.223 \%$ of consumers had knowledge about nutrition and 18.89\% in hygiene. Through media and school campaign, people could learn more told $34.447 \%$ and $58.887 \%$ said that media and the internet were the best way to learn more. Seventy- three percent consumers had idea about food borne pathogen and $74.443 \%$ told this pathogen sometimes caused diseases.

vii. Food safety perception and behavior of the consumer

It observed that $60 \%$ of the consumers suffered from diseases like diarrhea, stomach upset etc. To avoiding disease $62.223 \%$ consumers opinion ate less food.

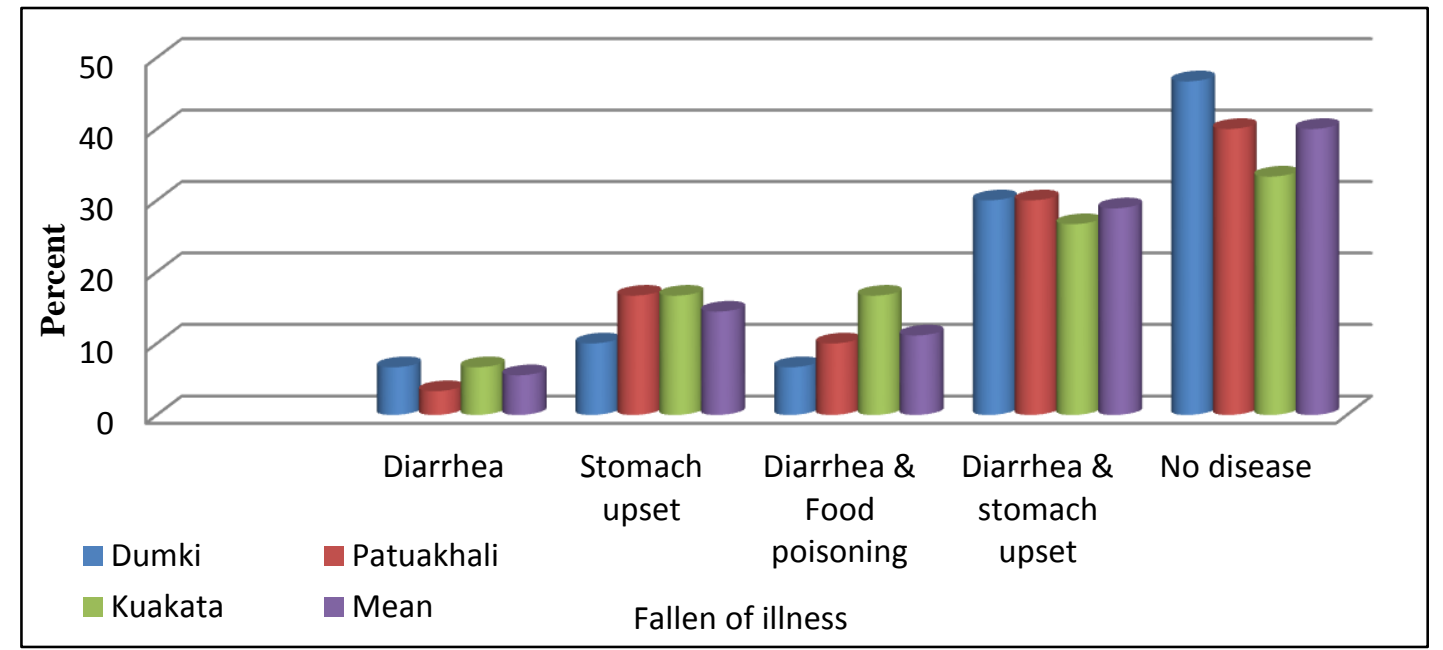

Figure 4: Types of disease afffect the consumer

viii. Criteria for choosing vendor of the consumer

Nearly $50 \%$ of consumers ate street food where the place was clean, and $83.333 \%$ shift where they found better option. Preferences of choosing a place $98.89 \%$ of consumers select cleanliness, $67.777 \%$ for freshness, $47.777 \%$ for time, and $30 \%$ for low price. c) Results of Microbial analysis

E. coli. and salmonella count in open restaurant foods About all food items contained E. coli. and salmonella. Water and salad fully contaminated by this microorganism.

Table 9: E. coli. Test of open restaurant food $(\mathrm{N}=5)$

\begin{tabular}{|c|c|c|c|c|c|c|c|c|c|}
\hline \multicolumn{10}{|c|}{ E. coli. test of open restaurant food } \\
\hline $\begin{array}{l}\text { Charact } \\
\text { eristics }\end{array}$ & Dumki & $\begin{array}{l}\text { Patuak } \\
\text { hali }\end{array}$ & $\begin{array}{l}\text { Kua } \\
\text { kata }\end{array}$ & Mean & $\begin{array}{l}\text { Character } \\
\text { istics }\end{array}$ & Dumki & $\begin{array}{l}\text { Patuak } \\
\text { hali }\end{array}$ & $\begin{array}{l}\text { Kua } \\
\text { kata }\end{array}$ & Mean \\
\hline \multicolumn{5}{|c|}{ Food item: Rice (\%) } & \multicolumn{5}{|c|}{ Food item: Khichuri (\%) } \\
\hline$-(\mathrm{ve})$ & 60 & 60 & 40 & 53.33 & - (ve) & 80 & 80 & 80 & 80 \\
\hline No & 40 & 40 & 60 & 46.67 & No & 20 & 20 & 20 & 20 \\
\hline \multicolumn{5}{|c|}{ Food item: Fish (\%) } & \multicolumn{5}{|c|}{ Food item: Biriani (\%) } \\
\hline$-(v e)$ & 80 & 60 & 80 & 73.33 & - (ve) & 40 & 40 & 60 & 46.67 \\
\hline No & 20 & 40 & 20 & 26.67 & No & 60 & 60 & 40 & 53.33 \\
\hline \multicolumn{5}{|c|}{ Food item: Egg curry (\%) } & \multicolumn{5}{|c|}{ Food item: Vegetables (\%) } \\
\hline
\end{tabular}




\begin{tabular}{|c|c|c|c|c|c|c|c|c|c|}
\hline - ve) & 0 & 40 & 0 & 13.33 & - (ve) & 80 & 60 & 60 & 66.67 \\
\hline No & 100 & 60 & 100 & 86.67 & No & 20 & 20 & 40 & 33.33 \\
\hline \multicolumn{5}{|c|}{ Food item: Meat (\%) } & \multicolumn{5}{|c|}{ Food item: Drinking Water (\%) } \\
\hline - ve) & 60 & 60 & 60 & 60 & - (ve) & 60 & 40 & 60 & 53.33 \\
\hline No & 40 & 40 & 40 & 40 & No & 40 & 60 & 40 & 46.67 \\
\hline \multicolumn{5}{|c|}{ Food item: Washing water (\%) } & \multicolumn{5}{|c|}{ Food item: Dal Charchori (\%) } \\
\hline$-v e)$ & 100 & 100 & 80 & 93.33 & - (ve) & 100 & 100 & 100 & 100 \\
\hline No & 0 & 0 & 20 & 6.67 & No & 0 & 0 & 0 & 0 \\
\hline \multicolumn{5}{|c|}{ Food item: Bread (\%) } & \multicolumn{5}{|c|}{ Food item: Potato varta (\%) } \\
\hline - ve) & 60 & 60 & 80 & 66.67 & - (ve) & 80 & 80 & 80 & 80 \\
\hline No & 40 & 40 & 20 & 33.33 & No & 20 & 20 & 20 & 20 \\
\hline
\end{tabular}

Maximum (83\%) of the sample bears gram-negative bacteria and Salmonella.

Table 10: Study of a positive sample of Salmonella

\begin{tabular}{|c|c|c|c|c|c|}
\hline Name of food & Sample size & E.coli.(- ve) & Percent (\%) & $\begin{array}{c}\text { Salmonella } \\
(+\mathrm{ve})\end{array}$ & Percent (\%) \\
\hline $\begin{array}{c}\text { Open Restaurant } \\
\text { food sample }\end{array}$ & 180 & 32 & 17.78 & 25 & 13.89 \\
\hline
\end{tabular}

\section{Discussion}

Maximum vendors (31\%) were between 21-40 years of age, which supports the data of the Bangkok where the average age is 36 years (FAO, 1994). Maximum food vendors $95 \%$ were male. But it is extremely opposite to other countries and cities like Bangkok where the female is $69.3 \%$ and Honduras, Indonesia, and Nigeria where percentage increases to $90 \%$ and above (FAO, 1990).

In Bangladesh, about 25\% of the men received help from their wives and $12 \%$ employed female helpers (Bhat \& Waghray, 2000). In contrast, other countries (e.g. Nigeria, Ghana, Uganda, and the Kenya) including Botswana, the majority of vendors are women who balance the income-generating opportunities of street vending with traditional household and child care duties (Mwangi, 2002).

In Mexico City (Muòoz de Chavez et al, 2000) found that men and women divided their tasks and responsibilities. Women cooked the food to be sold later in the day, while the men were responsible for buying all that was necessary for preparation of the food. Women worked an early shift in the stall, until about noon, when the men took over and stayed late. Men were responsible for cleaning the stalls, while women washed the utensils and dishes at home.

About $72.22 \%$ food vendors aged between 21 40 years with a mean age of years. Bhat and Waghray (2000) reported that the average age of the vendors in Asian countries were 20-45 years. Studies conducted in most Latin American Countries showed a similar trend compared to the one in Asian countries. In Jamaica however the age of vendors ranged from 14 to 78 years, with a mean age of $35.5 y e a r s$ and female vendors being older compared to their male counterparts (Bhat and Waghray, 2000)

A majority of the vendors displayed their foods in baskets/trays, bowl and shelves in survey area while vendors used showcase for display their food in Patuakhali and Kuakata areas.

The storage conditions were poor. The majority of the cases food stored at room temperature in plastic containers. The uncooked food products are left at ambient temperature for long periods.

Majority of the handler used stored water for cleaning utensils (68.89\%) followed by followed by pond and river water (15\%). Majority of handler used plate (27.78\%) followed by paper \& polythene $(49.45 \%)$ as a serving media. Tube well water used $100 \%$ as drinking water. It found that many vendors simply re-used the water, especially for cleaning utensils equipments and dishes due to difficulties in obtaining clean portable water (FAO and PAHO, 1985).

Hygiene during handling and cooking of street foods observed. It found that vendors did not wash fresh foods properly. Vendors did not wash their hands and utensils only once because they had not enough water. None of the cases, the vendors and the assistants did practice good personal hygiene; uniforms and aprons were not in use. Hanashiro et. al. (2005) examined microbiological quality of selected street foods from a restricted area of Sao Paulo city, Brazil and observed that personal hygiene of vendors during handling and cooking is very important as it causes serious health hazards to the consumers.

There was also hardly any inspection of the shops from the municipal or other appropriate 
authorities. This is similar to most developing countries which have no specific legislation or control systems for street food vending (Jayasuriya, 1994).

The most important finding of this study was the correlation between the socio- economic results regarding the hygiene practices of street vendors and the findings of the microbiological survey. The results of 5 other studies done among street food vendors in South Africa had similar conclusions (Mosupye FM et.al.2000).

This was a qualitative study of bacterial contamination for E. coli and Salmonella. Almost half (52.33\%) of the samples contaminated where $17.67 \%$ positive for E. coli. and, 15\% for salmonella in Open restaurant food. The positive case for Open restaurant food sample was 30 out of 180 sample (16.67\%). The positive for Open restaurant foods sample was 35 out of 180 samples (19.44\%) for salmonella.

\section{Conclusion}

Open restaurant foods have become a big part of the present-day urban scenario in many countries. The hygienic practices in question included food preparation, handling of utensils; a place for food preparation, personal hygiene, and methods of storing cooked food. Due to a lack of proper knowledge and guidance on food vending, vendors prepared it in explicitly unhygienic and unsanitary conditions. Improving the safety of food in any developing country is a great challenge. One of the major driving forces towards efforts to improve food vending is the contribution. As food vendors are doing their business without having a license, therefore, vendors are given clear legal status, so they can claim their entitlements to pursue their livelihoods. The vending foods contaminated with E. coli and Salmonella that causes a major health problem.

\section{References Références Referencias}

1. Ayalew, M. S., 2008, 'Safety of Street Food in Uganda', Intermediate Technology Food Chain, No 14.

2. FAO (1990). Food and Nutrition Paper 46 Street foods, Report of an FAO expert consultation, Jogjakarta. Indonesia 5-9 December 1998: Room

3. FAO (1994). Human nutrition in the developing world by Latham M.C., FAO Food and Nutrition Series No.29. Food and Agriculture Organization of the United Nations, Rome.

4. FAO (1988b). Food handling and street Food Preparation Practices, Particularly of Dairy Products in Kathmandu. Technical Report Project TCP/NEP/6755. Food and Agriculture Organization of the United Nations, Nepal (restricted).

5. Ohiokpehai, 2003 "Food Hygiene with reference to public health" Page: 86: 53-99.
6. Potter N. N. (1978). "Food Science", Third ed. CBS publishers \& Distributors, $\mathrm{p}-64$.

7. Codjia, G. 2000. FAO technical support for improvement within the street food sector. Pretoria. 86: 123-137.

8. Mwangi, A. 2002. Nutritional, hygienic and socialeconomic dimensions of street foods in urban areas: The case of Nairobi. (Unpublished Doctoral thesis): University of Wageningen, The Netherlands, 43, 91and 108.

9. Muòoz de Chávez, M., Villasana, A.C., Mu òoz, M.C. and Vuskovic, I.E. 2000. Sale of street food in Latin America. In: Simopoulos, A.P. Bhat, R.V. (eds.), Street foods. World Review of Nutrition and Dietetics. Basel: Karger, 86: 53-99.

10. Bhat, R.V., Waghray, K. 2000. Profile of street foods sold in Asian countries. In: Simopoulos, A.P. Bhat, R.V. (eds.), Street foods. World Review of Nutrition and Diabetics. Basel: Karger, 86: 53-99.

11. FAO, PAHO (1985). Inform del Taller FAO/OPS Latin America no Sobre Alimentos Vendidos en la via Publica, 2I-25 October 1985, Lima, Peru. Pan American Health Organization, Washington, DC.

12. Hanashiro, A., Morita, M., Matte, G.R., Matte, M.H, Torres, E.A.F.S. 2005. Microbiological quality of selected street foods from a restricted area of Sao Paulo city, Brazil. Food Control, 16: 439-444.

13. Jayasuriya, D.C. 1994. Street food vending in Asia: Some policy and legal aspects. Food Control, 5: 222-226.

14. Mosupye FM, Van Holy A. 2000. Microbiological hazard identification and exposure assessment of street food vending in Johannesburg, South Africa. International Journal of Food Microbiology. 61: 137-145 